\title{
Martin Luther on Deësis. His Rejection of the Artistic Representation of "Jesus, John, and Mary"
}

FRANZ

POSSET

Summary: At times, Reformation scholars and art historians are confused about Luther's attitude toward the visual arts which depict saints as intermediaries between God and humanity. Rarely do they thematize the issue in relation to the deësis, i.e. Christ enthroned, with Mary and John the Baptist as intercessors. After a review of the wide-spread motifof the deësis, light is being shed on Luther's statements of the 1530s which reflect his rejection of the motif.

$\mathrm{O}$ ccasionally, one may observe some confusion among Reformation scholars and art historians in regard to Martin Luther's attitude towards the visual arts, in particular to depictions which represent saints as intermediaries between God and humanity, and in regard to the motif called deësis. The present investigation has the very limited purpose of clarifying what Luther may have had in mind when he rejected certain depictions of Jesus, John the Baptist, and Mary - a topic rarely included in studies on Luther's Reformation and the arts. Without using iconographic terms, Luther criticized such depictions from his own specific theological point of view.

There are basically two motifs in traditional Christian art that show Mary and John together with Christ/God. However, the problem is to determine which "John" is meant. John the Apostle appears with Mary under the cross of Christ, while John the Baptist appears with Mary in representations of intercessions before Christ enthroned. It is my thesis that Luther objected to the latter, which is the motif of "entreaty"/ "intercession," the so-called deësis. It has its origins in Byzantine art and spirituality. 
58 / Renaissance and Reformation / Renaissance et Réforme

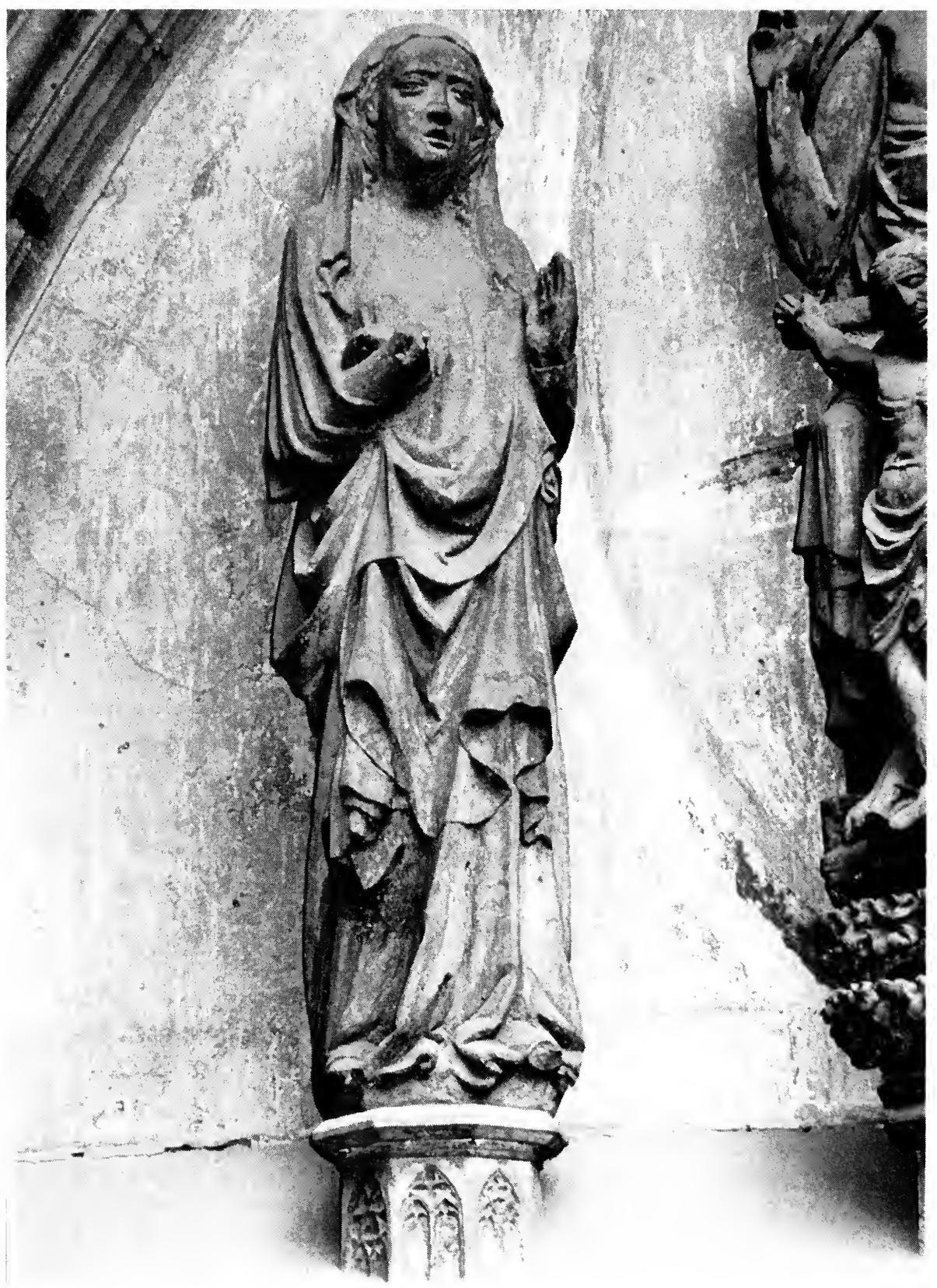

Fig. 1: (Detail) Mary as part of the deësis sculpture at Erfurt's Dom. Used with permission of Erfurt Dom. 
Art historians identify the composition as follows: Christ/God (in heaven) is flanked by Mary (left) and by John the Baptist (right). ' Of all the saints, why is the Baptizer included? He is shown to represent the first person (other than Mary) who recognized Christ, and thus he is paralleled visually and devotionally to Mary. At times he is followed by figures from the so-called Old Testament.

Since Jesus, John, and Mary, as found in deësis compositions, are to be featured here, the issue of who the donors or beneficiaries were for whom the intercession was made, will be neglected. The beneficiaries may have been the souls in purgatory, or specific persons, dead or alive, who financed the painting; or the depietion of the deësis may function as a reminder to do penance or pass just judgment in earthly affairs. Luther does not specify which artistic depictions of "Mary and John" he had in mind. In order to shed light on the Reformer's criticism and in order to show how wide-spread the artistic motif was, a brief review of this intercession motif shall be presented here first, including a correction which needs to be made concerning the oldest deësis motifs in Western art.

\section{The Deësis Motif}

The new Dictionary of Christian Art (1994) mistakenly assures us that the Ghent Altarpiece by the van Eyck brothers, the famous example of early Renaissance art from the fifteenth century, depicts "the first western presentation of the deësis." This statement is incorrect because there are older depictions of the deësis motif in the West, such as the mosaic, called the Byzantine Last Judgment, on the west wall of the Cathedral at Torcello (Upper Italy) from the early eleventh century. The mosaic contains numerous scenes, but has at its center the deësis: "Mary and John" (the Baptist) shown as petitioners as they flank Christ sitting on the rainbow in the mandorla, holding both hands in a welcoming gesture, and displaying the marks of crucifixion on hands and feet. ${ }^{3}$

Furthermore, the deësis motif is found in an anonymous French diptych made of ivory from around $1260-70 .{ }^{4} \mathrm{By}$ the time of the High Renaissance, this motif became the central grouping in representations of the Last Judgment. At times, John the Baptist is shown (in deësis compositions) with figures from the Hebrew Bible (Old Testament) placed behind him, perhaps representing the people of Israel, as, for instance, seen in the so-called Disputa by Raphael $(+1520)$, which contains the deësis motif in the middle register. There are many more figures incorporated into this picture. ${ }^{5}$

A survey of 300 years of Christian art north of the Alps would demonstrate the popularity of the deësis motif, starting after 1200 and leading up to the early 


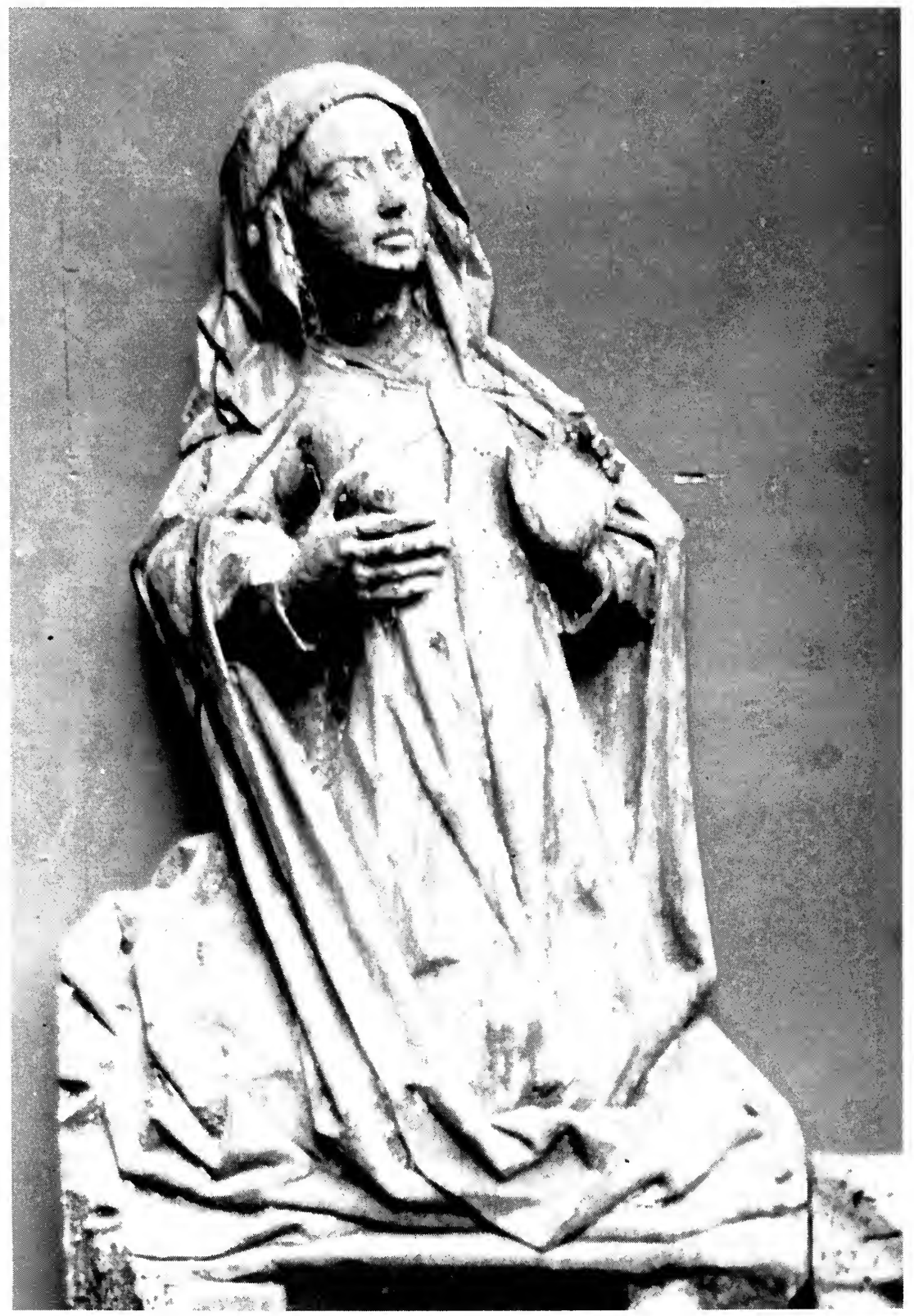

Fig. 2: Detail from the Trammer Altar Deësis, Lübeck, Germany, second half of the 15 th century. Used with permission of Museum für Kunst und Kulturgeschichte der Hansestadt Lübeck. 
sixteenth century, when the motif came under attack from Martin Luther. A detailed survey cannot be presented here due to space restriction. A few hints at depictions from mostly German speaking lands must suffice.

One of the early depictions of our motif is found in a psalter manuscript from 1211-13, originating probably in Lower Saxony. The text related to this depiction speaks of the intercession by Mary, John, and all choirs of saints before God. ${ }^{6}$ From around 1260, an embroidered antependium is extant, today at Helmstedt, Lower Saxony, on which we see Christ in the mandorla, with Mary and John the Baptist. ${ }^{7}$ Our motif also appears on a thirteenth-century altarpiece painting in Soest in northern Germany. ${ }^{8}$ The oldest deësis in sculpture form in Germany (to my knowledge) is extant only in theoretical reconstruction from the Augustinian church at Mainz. ${ }^{9}$ Another sculpture is found on the outside of the western entrance of Erfurt's main church (Dom), which was built in the fourteenth century.

In this Erfurt deësis John holds a disk in his left hand with the Lamb of God and its victory banner. John's other hand appears to point to the lamb. The disk may represent the nimbus of the Lamb of God. It is in the Erfurt church that Luther was ordained to the priesthood. While the Erfurt deësis presents the usual arrangement with Mary on the left and John the Baptist on the right of the Godhead, Christ is not depicted by himself, but together with the benevolent Father whose hands appear raised in a gesture of blessing, while keeping the cross with the crucified Christ in his lap. This composition is called Mercy Seat which is combined here with the deësis motif. ${ }^{10}$ Also from the fourteenth century, there are 27 pictures of the "Life of Christ and Saints" which contain a scene of the Last Judgment as a typical deësis composition. ${ }^{11}$

From the fifteenth century there exist several depictions of the motif besides the van Eyck brothers' known Ghent Altarpiece: ${ }^{12}$ for example, a painting of app. 1435 attributed to the studio of Stephan Lochner, $(+1451){ }^{13}$ an altarpiece for the Lamberti church at Hildesheim, Germany, ${ }^{14}$ the center panels of the Last Judgment by Rogier van der Weyden from about $1450{ }^{15}$ From about the same time we find a blanket at Nuremberg, which was used for a funeral (Grabteppich, Bahrtuch), and which has the deësis motif woven into it. ${ }^{16}$ Also at around 1450 , the same motif is found in a book illustration at the beginning of the Seven Penitential Psalms, and then also as part of an ivory diptych, originally from France. ${ }^{17}$

In the second half of the fifteenth century our motif is found in sculptured form with the Trammer Altar at Lübeck, Germany and then also in the middle Rhine valley showing "Mary and John" as advocates before the Judge. ${ }^{18}$ In 
contrast to earlier depictions of the deësis (where Mary is not shown with her bare breast), in these two fifteenth-century representations Mary is shown with one breast exposed as she appears to gesticulate before Christ in her attempts to intercede on behalf of the sinners. From this relatively late appearance of Mary's exposed breast within the deësis compositions one may conclude that the exposed breast of Mary was not essential to the deësis. However, by definition, her petitioning position in symmetry with John the Baptist in front of the enthroned Christ is essential to it.

The bare breast motif appears to have entered the deësis compositions under the influence of the medieval chain of intercessions, the hierarchical "stairway" mentality (in German: Heilstreppe). There are corresponding depictions in which Mary at the lower level is seen showing her bare breast to her Son as the Man of Sorrows (slightly elevated, but not the enthroned Christ!), who in turn shows his side wound to the Father on high, pleading for mercy on the sinners. Such a combination of motifs suggested itself since both elements (deësis and "stairway") originally are intercession motifs. ${ }^{19}$

Pictures from the fifteenth century Speculum humanae salvationis usually include the deësis motif toward the end of the books. ${ }^{20}$ At Cologne, a painting with our motif came in existence at about 1425; and elsewhere at about 1475 a small altar painting with the same motif was created. ${ }^{21}$ Simon Marmion produced a book illustration at about 1480 containing the deësis. ${ }^{22}$ In the Dom at Graz, Austria, a gigantic mural from 1485 incorporated among many other figures the deësis concept. ${ }^{23}$ Our motif also appears on the central altarpiece from 1488 at a Regensburg church ${ }^{24}$ in a painting of the Master of St. Severin (Cologne), ${ }^{25}$ and in one which is attributed to the Master of Mary's Glory. ${ }^{26}$ In 1493 the "Christian World History" of Dr. Hartmann Schedel was published at Nuremberg in Latin and then in German. This book concludes with the image of the Last Judgment and the traditional deësis composition. ${ }^{27}$

In 1504, the Master of Alkmaar included the deësis motif in one of his Seven Acts of Charity, i.e. burying the dead. ${ }^{28}$ In 1505 Hans Baldung produced a woodcut with the same motif and all its familiar characteristics. ${ }^{29}$ Also at around 1505, Hans Holbein the Elder provided the draft for the painted glass window at the mortuarium of the Domkreuzgang at Eichstätt with the deësis as its chief composition element. ${ }^{30}$ In the Adoration of the Trinity of 1508-1511 Albrecht Dürer (who later displayed interest in Luther's reform) utilized the deësis motif. However, in Dürer's work, Christ is not portrayed as judge in the familiar position sitting on the rainbow, but is shown hanging on the cross, held by God the Father over whose head appears the dove symbolizing the Holy 
Spirit. Mary and John are positioned as usual. ${ }^{31}$ This Mercy Seat motif was found already in the Erfurt deësis, mentioned above. Also from Dürer, we have the Kleine Passion with 37 woodcuts, printed in 1511, which includes the deësis motif in the scene of the Last Judgment. ${ }^{32}$ The Wittenberg court painter, Lucas Cranach, used the deësis composition at least twice. We find it in his painting called At Death's Door from c. 1518, and also in his Last Judgment, which was created between 1520 and $1525 .{ }^{33}$ In a 1520 manuscript, the same composition, used by the Master of St. Severin (Cologne) around 1488, reappears, except that in the later composition Christ raises both hands in blessing and his feet rest on the globe..$^{34}$

Also at the beginning of the sixteenth century, Hieronymus Bosch $(+1516)$ incorporated the deësis into his Last Judgment. The two prominent intercessors, Mary and John, are relegated, however, to a position behind and above Christ. With the arrangement of the deësis in this way, Bosch stated with his artistic means - that the time for intercession had passed. ${ }^{35}$ This is a unique arrangement, not often observed in depictions of this motif. A similar, less prominent, positioning also appears to be the case with Jan Provost who used the deësis as composition element in his two variations of the Last Judgment (1525). In his first Variation Provost placed Mary and John on clouds into the far upper corners. ${ }^{36} \mathrm{On}$ the left, Mary exposes one of her breasts; John is positioned as usual on the right side. Yet, they hardly seem to have any intercession function any more. In Variation 2, the two intercessors take up a more visible position than in Variation 1. We see Queen Mary leading the Apostle Peter with the keys to the kingdom of heaven, accompanied by other figures. The Baptist, on the right, is shown with the Lamb of God in front of him as he leads a group of figures from the Old Testament, including Moses, who is shown holding the two Ten Commandments tables. In Variation 2, Christ is shown as the merciful Judge who holds the sword of judgment in his left hand, but points to his side wound with his right hand, i.e. to the symbol of his salvific suffering out of love for humanity ${ }^{37}$ One may have difficulties with C.W. Bynum's interpretation that the artist allegedly emphasized "the parallel between Christ's wound and Mary's breast," and that Christ is supposedly the "judge and avenger" (the latter, no; the former, yes). Bynum completely ignores the deësis as the chief composition element (Jesus, John and Mary), and therefore she probably overinterpreted Provost's painting (Variation 2) when she writes that "The modest motion by which Mary's fingers lift up her breast clearly recapitulates Christ's almost cradling gesture toward the wound that saves the world." ${ }^{38}$ In conclusion of our survey one 
needs to mention a piece from around 1525, when the artist Jörg Kändel from Biberach in Southern Germany used Hans Baldung's woodcut as his model when he painted the deësis with all of Baldung's specifics on the back of a shrine altar for the church at Seewis in Switzerland. ${ }^{39}$

Having sampled more than 30 deësis compositions up to the time of Luther, and pointed out the significance of recognizing the deësis as a basic composition element, it becomes evident that the motif has had a long history and has been widely used in German speaking lands for the depiction of the "intercession" at the Last Judgment. With sixteenth-century artists such as Bosch and Provost we observed the relegation of Mary and John from their prominent positions without deleting them altogether. These later artists seem to have anticipated with their paint brushes what Luther articulated with his pen.

\section{Luther on Depiction of the Deësis}

It was as late as 1531, after the Augsburg Confession, and almost a decade after the iconoclastic riots at Wittenberg, that Luther criticized the deësis in the context of his comments on Bernard of Clairvaux. Although Luther quoted Bernard de Clairvaux rather sympathetically, ${ }^{40}$ he also considered him as being the unfortunate spiritual source for this artistic depiction. Luther appears to have in mind two originally completely separate motifs. The first motif shows Christ in kneeling position, as petitioner before the Father, and Mary petitioning her Son - the figure of John is not included at all in this motif. The second motif shows Christ enthroned, himself being petitioned by both Mary and John the Baptist, in what is the classical deësis motif.

Here is Luther's first remark on this issue:

... St. John and Mary (are) asking Christ for us on the Last Day; and [that] the mother shows her breasts to the Son who sucked on them. This is taken from St. Bernard's books, and it is not spoken nor painted nor done well by St. Bernard, and one should put away these depictions. ${ }^{41}$

Evidently, Luther instigated some limited iconoclasm here.

However, we do not know exactly what artistic depiction(s) Luther wanted to do away with. Apparently, several images converge in Luther's eyes in 1531: there is the blurred remembrance of a deësis depiction which Luther may have had in mind, possibly one of the following: the deësis at the Erfurt Dom where he was ordained to the priesthood; the already mentioned paintings by the contemporaneous Wittenberg court artist Lucas Cranach; ${ }^{42}$ or the 
woodcut in one of the many Speculum humanae salvationis books, the one in Hartmann Schedel's Liber chronicarum ${ }^{43}$ or a depiction by Dürer. Of course, there is always the possibility that Luther knew of a picture which was destroyed during the iconoclastic riots instigated by certain Reformers. If Luther was thinking of the Erfurt sculpture, which is the combination of the Mercy Seat with the deësis motif, he would have disregarded the fact that this is a depiction of a merciful Godhead, and not of an angry God.

The deësis representations (known to me within the German tradition) which depict Mary exposing her breast and which thus would be a partial match with Luther's text, are the 1460-1470 representations from the middle Rhine valley, the Trammer Altar of Lübeck, and the Speculum woodcuts. However, these representations show only Christ enthroned (not the Father!), and thus they do not fit well with Luther's text which precedes the quote given above, namely that "it is a shameful and blasphemous image or painting of the Last Judgment when one painted the Son falling down in front of the Father showing Him his wounds." ${ }^{44}$ We can solve the problem posed by Luther's remark, if we assume that at least two, if not three, different motifs entered Luther's text. The passage apparently contains a confluence of the deësis motif, i.e. "St. John and Mary asking Christ for us on the Last Day," as Luther's words have it, and of the other motif which is described by Luther as "the Son falling down in front of the Father showing him his wounds," itself combined with the depiction of "the mother showing her breasts to the Son who sucked on them," which is the motif found in depictions of the Tribunal of Mercy or the Stairway to Salvation. In it the sinner is led to Mary who is expected to intervene before her Son; she exposes her breast as a reminder that she has nurtured him. The Son as Man of Sorrows petitions the Father and shows him his stigmata as a reminder that he suffered for the redemption of the sinners and thus should not be damned eternally.

At about the time of Luther's first mention of Bernard and the deësis in connection with the disliked depictions of Mary and John, the Reformer actually spoke rather favorably of a depiction of the Virgin and the Christ child in a Table Talk of 1532, which demonstrates that Luther was not opposed to the artistic expression of Christian spirituality as such. While talking he apparently pointed to a painting on the wall of his dining room which depicted Mary with the Christ child in her arms; he then said: "The Infant Jesus sleeps in the arms of the Mother of God: when he awakens, he will ask us what we have done and how we have behaved." 45 The painter of this picture is not mentioned. But Luther apparently esteemed depictions of Mary as mother with 
her child, if they enhanced his theology of the incarnation, and if they featured nothing but Mary as a humble woman. In contrast, he objected to any spirituality (and concurring depictions) which made Mary a mighty mother and which made her and saints like John the Baptist almost more important than Christ (as Luther perceived it).

To the Reformer, religious pictures had value only insofar as they assisted in preaching and promoting Christ. ${ }^{46}$ This was the theological stand point from where Luther evaluated spirituality and its artistic expressions. His christological interest and Christ-centered spirituality completely dominated his religious outlook. Apparently, only the Mary in humility (umiltà, in Italian Renaissance art) in "her great poverty," not the Mary in maestà, should be shown, as she is the one who united her own insignificance with "the glory of God." ${ }^{47}$ With this preference, Luther appeared to have favored the artistic trends of the Italian Renaissance which since about 1350 depicted a humble Mary, nurturing the baby in the garden.

Luther mentioned "Mary and John" (= deësis motif) a second time in his 1533 sermon (on Luke 21) for the second Sunday of Advent. Luther spoke about the priority of Christ, and he again complained about previous aberrations based on a dubious (in his opinion) spirituality which was not Christocentric: "Christ as Redeemer was not talked about; instead he was painted like a judge with rod and sword, i.e. being angry, as he wanted to punish the world; then they depicted John and Mary; to them we ran." ${ }^{48}$ In the context of this particular Advent sermon the Reformer contrapositioned Bernard and the Bible ("But no, the [biblical] text says"). Luther mistakenly assumed again Bernard to be the source of representations of Christ primarily as Judge. Luther focused here on the Advent theme and also on the late medieval emphasis on Christ coming in Judgment ${ }^{49}$ along with the disliked artistic deësis composition. He saw all this as a distortion of the biblical message insofar as in that message there is more to Christ than his being the merciless Judge, and that there is no basis in the Bible for John the Baptist and Mary to be construed as significant intercessors for all sinners on the day of Judgment.

We have isolated two completely different artistic motifs for the depiction of intercessions: (1) Mary and John the Baptist present their petitions in front of the adult Christ enthroned, i.e. the deësis; (2) Mary with exposed breast petitioning her adult Son, and in turn Christ - with exposed side wound - is petitioning the heavenly Father who is perceived as angry and who is to be pacified and mitigated. John the Baptist is not part of the latter motif at all. Having these motifs taken apart, one can no longer maintain the all too hasty 
assumption that Luther meant "John, the Apostle," since the Apostle John does not appear in art history as a petitioner at the Last Judgment in partnership with Mary. Most recently, such an equation (John = the Apostle) can be found in a study by Theo Bell who interpreted Luther's mention of "John" in 1533 to mean the "Apostle." ${ }^{50}$ However, Bell overlooked the fact that Luther's remarks are concerned with the issue of "intercession by the saints" on Judgment Day and that in Christian art John the Apostle/Evangelist is never found as intercessor or advocate together with Mary as mediatrix before the enthroned Christ. It is always John the Baptist who is part of the various intercession/ deësis compositions. Not having recognized that Luther had some sort of deësis depictions in mind when he talked of "Mary and John," Bell is also mistaken in his opinion that Luther had in mind the "scene under the cross" with Mary and the Apostle John. ${ }^{51}$ Luther explicitly spoke of judgment scenes when he criticized certain depictions with "Mary and John." These Judgment scenes are deësis scenes and not crucifixion scenes!

In the same breath, Luther mentioned Mary with her exposed breast. However, Mary standing under the cross is never shown with bare breast. The gesture towards her breast is either part of the deësis or part of the "intercession chain" which leads from Mary via the Son to the heavenly Father, or part of the so-called "double intercession" by Mary and Christ as the "Man of Sorrows." Furthermore, Luther clearly spoke of Christ kneeling and as showing his side wound to the heavenly Father. Luther obviously had in mind the intercession images known also as Tribunal of Mercy which, however, do not have John the Baptist in the picture at all, but Mary and Christ as intercessors before the Father. They are completely different from the motif of "Mary and John" (the Baptist) as intercessors before the enthroned Christ. Finally, it needs to be pointed out that in 1538 Luther himself spoke explicitly of John the Baptist, when he criticized once more medieval spirituality which had made Christ the strict Judge with "Mary and John the Baptist" flanking him as intercessors: "They make out of Christ nothing but a strict, angry judge of whom one has to be afraid, as he wants to throw us into hell; in this way one has painted him as sitting in judgment, on the rainbow, with his mother Mary and John the Baptist on each side as intercessors against his terrible anger." 52

Luther must have had a rather concrete representation of "Mary and John" in mind whom he took as having the roles of pacifying the enraged Godfather. In contrast to that, according to Luther's Reformational message, God is not merciless, but merciful. The late medieval image of an angry Judge (if isolated from the rest of the Biblical message) was intolerable to him. Such a concept 
had called for the motherly mitigation and intervention, i.e. for Mary as the advocata before the Judge, as she is assisted by John the Baptist. Luther objected to the intercession and advocacy by Mary and John the Baptist, because he preferred the direct intercession through Christ as our advocatus, as he is called in the Latin version of the First Letter of John: "We have an advocate with the Father, the just Jesus Christ;" advocatum habemus apud Patrem, lesum Christum iustum (1 John 2: 1) ${ }^{53}$ Luther drew further support from 1 Tim 2: 5: "God is one. One also is the mediator between God and men, the man Christ Jesus." Through his theological objections to the medieval spirituality's intercession system in popular devotion, Luther simultaneously (and probably unknowingly) turned away from the Greek Orthodox concept of the deësis as "entreaty" by the Mother of God and John the Baptist, which after its transfer from the East was at work in medieval and Renaissance art.

Bell's recent book on Bernard and Luther is therefore deficient in clarity concerning this iconography. So are other researchers, who in their iconographic studies on the relationship between art and the Reformation hardly come to speak of Luther and the deësis, and of Luther's role in the transformation of the images of judgment. Very often nothing is said about the Reformer's criticism of visual representations of "Mary and John" and their intercessions at the Last Judgment. ${ }^{54}$

Luther's criticism of the depictions of the intercession motif was heeded by Lucas Cranach, who was favorably inclined towards Luther's reforms. Cranach processed the motif in his own way. In his depiction of The Fall and Salvation of Man, dated 1529, he retained the traditional deësis motif which is clearly visible on the left as part of the Old Testament. Up in the clouds Christ appears as Judge of the world, flanked by Mary on the left, and by John on the right, in the typical deësis constellation. However, remarkably, Cranach assigned this motif to the Old Testament side of his composition, which includes Adam and Eve in the Garden of Eden, shown after the Fall submitting to the Law of Moses. Thus, for Cranach the deësis motif belonged to the old order. Separated by a tree at the center, the New Testament side of the entire composition shows again John the Baptist as he directs the sinner to Christ on the cross. From the Christ's side wound a straight stream of blood with the Dove of the Holy Spirit is directed toward the head of the professing sinner. The risen Lord pointing with his right hand toward heaven is soaring above his tomb and the cross.

In depicting the basic notions of the Reformation - salvation by faith and grace, not by law and intercessions - Cranach expressed Luther's theological position and discarded altogether the concept of deësis. ${ }^{55}$ Luther's rejection of 
the deësis was a consequence of his mode of theologizing and his pastoral care. As Luther aimed at simplicity in his exegetical, literary, and homiletic work, he wanted to see this principle realized also in religious art. In one of his Table Talks Luther raised this issue and quoted an alleged utterance by Albrecht Dürer (as noted by Aurifaber): "Doctor Luther once said that Albrecht Dürer, the famous painter, used to say: "I like pictures that are painted as simply as possible"... Likewise I would like to deliver the simplest possible sermon that every believer could understand." 56

The battle between Reformers and Counter-Reformers was not over: against Luther's reduction and simplification of Christian spirituality and art, the Counter-Reformation leaders tried early on to maintain the traditional deësis concept. John Eck, for instance, the great adversary of Luther, had a German translation of the Bible printed in 1537 which shows on its title page (by Holbein!) the decisive figures of the deësis: the Trinity with "Mary and John." The twelve apostles are included along with other saints. ${ }^{57}$ Evidently, in times of heightened theological sensitivities as we encounter them in the early sixteenth century in Europe, the issue of deësis was not insignificant, even though the problem of religious art (and church music, by the way) was considered part of the fairly neutral field of adiaphora. ${ }^{58}$ Yet, the issue was hotly debated and depicted as can be seen in the 1544 woodcut by Lucas Cranach the Younger, who created a flyer on the difference between the true religion of Christ and the blasphemous Antichrist. ${ }^{59}$ In it Cranach showed on the side of the true religion the Lutheran concept of Christ's sole mediation; on the right side, inspired by the Holy Spirit hovering over Luther's head in the form of the dove, Luther appears as preacher of acts 4:10, "Then you and all the people of Israel must realize that it was done in the name of Jesus ...., saying that "all the prophets give witness of Him, that there is no other name under the sky," written on Luther's pulpit as his comment. Luther - like John the Baptist (whom the artist, however, "replaced" with Luther the preacher - points to the elevated Lamb of God, whereby the banderole between Luther and the Lamb of God contains the Baptist's words: "See the Lamb of God." The banderole between the Lamb and the yet higher Christ figure reads: "I am the Way." In front of Christ, shown with his hands folded, his wounds on his hand clearly visible, crowned with the crown of thorns, the banderole says: "There is only one mediator" (1 Tim 2: 5). Christ addresses the heavenly Father with words written between his and the Father's head: "Father, sanctify them. I sanctify and offer myself for them with my wounds." The counter picture illustrates what the artist perceived as Roman Catholic blasphemies, in which Christ could not be not found at all. The irate 
Father in heaven lets hail rain down on these blasphemers, while saint Francis as a helpless (and thus useless) intercessor has to watch this punishment since he cannot prevent it with his petitions.

By way of summary, we may point to another concrete effect and result on Luther's theological objection to the art scene of the later sixteenth century. In the Lutheran town church at Heilsbronn, Lutheran teaching on Christ as the only advocate was expressed in a painting of $1560-1570$. In this painting the deësis of "Mary and John" is completely deleted. Christ is shown alone as the only advocate in front of the Father. ${ }^{60}$ At that point in time Luther's christocentrism had reduced Mary's prominent function as the heavenly intermediary, advocata, fürsprecherin to a more simple "prayer leader," Vorbeterin. ${ }^{61}$

Beaver Dam, Wisconsin, USA

\section{Notes}

1. Cf. Th. von Boggay, entry "Deésis," in Klaus Wessel, ed. Reallexikon zur byzantinischen Kunst (Stuttgart: Anton Hiersemann, 1966) vol. 1: 1178-86. Diane Apostolos-Cappadona, Dictionary of Christian Art (New York: Continuum, 1994), entry “Deesis [sic]," p. 101, and entry "Last Judgement," pp. 205-206.

2. Cf. Apostolos-Cappadona, Dictionary of Christian Art, entry “Eyck," p. 126. - A very large fragmentary mosaic from the late thirteenth century representating the deësis is found in the south gallery of Hagia Sophia in Istanbul with the three figures on the same level. This is mentioned here in passing as it is an Eastern representation, while our focus is on developments in Western Christian art. Cf. Frederick Hartt, Art. A History of Painting, Sculpture, Architecture (New York: Harry N. Abrams, 1976) Vol. 1, pp. 363-64, with illustration no. 441.

3. Cf. Caroline Walker Bynum, Fragmentation and Redemption: Essays on Gender and the Human Body in Medieval Religion (New York: Zone Books, 1991), p. 286, illustration 7.11; Bynum, however, does not discuss this image in terms of deësis; V. H. Elbern, entry "Gericht," Lexikon für Theologie und Kirche, vol. 4: 729, cf. pp. 736-37; (Torcello) illustration 1.

4. The ivory diptych is depicted in Henk van Os, The Art of Devotion in the Late Middle Ages in Europe 1300-1500 (Princeton: Princeton University Press, 1994), p. 27; today in The Metropolitan Museum of Art, New York.

5. Cf. John Ives Sewall, A History of Western Art (New York: Holt, Rinehart and Winston, 1961), pp. 592-93 (photograph and diagram; the painting is in the Vatican).

6. Cf. Miniature in the so-called "Landgrafenpsalter" in Die Zeit der Staufer (Stuttgart: Württembergisches Landesmuseum, 1977) Exhibition Catalogue vol 1: ill. no. 558 with text in vol. 2: no. 764 . 
7. Mary has her hands stretched out toward Christ. John holds the lamb. It is generally assumed that the antependium belonged to the Augustinian nuns at Heiningen, south of Wolffenbüttel. Cf. Die Zeit der Staufer, vol. 1: ill. no. 591 with text in vol 2: no. 798.

8. The Trinity is flanked by Mary and John in their traditional places, with their hands in similar positions as seen on the antependium. Cf. Colin Platt, The Atlas of Medieval Man (New York: Crescent Books, 1979), p. 105.

9. Fritz Arens, “'Der Figurenzyklus des Grossen Weltgerichts' im Dommuseum und der Lettner der Augustinerkirche in Mainz," Städel-Jahrbuch, 8 (1981), pp. 57-66.

10. Cf. E. Lehmann and E. Schubert, Dom und Severikirche zu Erfurt (Leipzig, 1988), p. 149, ill. no. 15. On John and the Lamb of God within the deësis at the Erfurt Dom, cf. Christoph Markschies, “'Hie ist das recht Osterlamm.' Christuslamm und Lammsymbolik bei Martin Luther und Lucas Cranach," Zeitschrift für Kirchengeschichte, 102 (1991), 209-30, here p. 211.

11. Cf. Robert Suckale, “Arma Christi. Überlegungen zur Zeichenhaftigkeit mittelalterlicher Andachtsbilder, Städel-Jahrbuch, 6 (1977), 177-208, here p. 198, ill. 11 (Cologne, appr. 1360, Wallraf-Richartz Museum).

12. Cf. Apostolos-Cappadona, Dictionary of Christian Art, entry "Last Judgment," p. 205.

13. Lochner's piece, in Cologne: ill. no. 13 within the entry “Gericht," by V. H. Elbern, Lexikon für Theologie und Kirche, vol.4, p. 729. Cf. Craig Harbison, The Last Judgment in SixteenthCentury Northern Europe (New York: Garland, 1976), pp. 115f; Ines Cresel, Dietmar Lüdke, and Horst Vey, eds., Christus und Maria: Auslegungen christlicher Gemälde der Spätgotik und Frührenaissance aus der Karlsruher Kunsthalle (Karlsruhe: Staatliche Kunsthalle, 1992), p. 53, ill. no. 51.

14. Cf. Kurt Löcher, "Das jüngste Gericht," Anzeiger des Germanischen National Museums Nürnberg (1979), pp. 172-75, quoted in Martin Luther und die Reformation in Deutschland. Ausstellung zum 500. Geburtstag Martin Luthers Veranstaltet vom Germanischen Nationalmuseum Nürnberg in Zusammenarbeitmit dem Verein für Reformationsgeschichte (Frankfurt: Insel-Verlag, 1983), pp. 129-30 (no. 147); this exhibition catalogue is referred to from here on as Luther Exhibition 1983.

15. Second opening with a total of nine paintings: cf. Das grosse Buch der Kunst. Bildband Kunstgeschichte Lexikon, eds. Bert Bilzer, Jürgen Eyssen, and Fritz Winzer (Braunschweig: Westermann, 1979), pp. 134-35, in color; Apostolos-Cappadona, Dictionary of Christian Art, p. 127 has it in black and white.

16. Cf. Luther Exhibition 1983, 55, no. 55.

17. Peter Jezler, Himmel, Hölle, Fegefeuer. Das Jenseits im Mittelalter, exhibition catalogue (Zürich: Verlag Neue Züricher Zeitung, 1994), p. 209, ill. no. 32. On the ivory diptych, Meuse Valley, mid-fourteenth century, today in Rijksmuseum, Amsterdam, cf. Henk van Os, The Art of Devotion in the Late Middle Ages in Europe 1300-1500, p. 11, plate 1.

18. Cf. Hildegard Vogeler, Madonnen in Lübeck. Ein ikonographisches Verzeichnis der 
mittelalterlichen Mariendarstellungen in den Kirchen und ehemaligen Klöstern der Alstadt und des St. Annen-Museums (Lübeck: Museum für Kunst und Kulturgeschichte, 1993), p. 127. For the painting from the Rhine Valley, cf. Luther Exhibition 1983, 335, no. 444.

19. The bare breast motif within depictions of intercession is found decades earlier than the Trammer Altar; for instance, at about 1400, in the St. Proclus Chapel at Naturns in South Tyrol; cf. Leopold Kretzenbacher, "Schutz- und Bittgebärden der Gottesmutter. Zu Vorbedingungen, Auftreten und Nachleben mittelalterlicher Fürbitte-Gesten zwischen Hochkunst, Legende und Volksglauben," Bayerische Akademie der Wissenschaften, Philosophisch-historische Klasse (Munich: Verlag der Bayerische Akademie der Wissenschaften, 1981), Heft 3,1-112, ill. 3; then also in the first half of the fourteenth century in the glass window at Freiburg, cf. Jezler, p. 81, ill. 49. The motif of Mary's bare breast may be inspired by Cistercian spirituality, namely by Ernald of Bonneval (died 1156), cf. Patrologia Latina, 189: 1726.

20. Cf. Adrian Wilson and Joyce Lancaster Wilson, A Medieval Mirror. Speculum Humanae Salvationis 1324-1500 (Berkeley: The University of California Press, 1984), p. 198: woodcut (Mary with exposed breast). The miniature in the manuscript from 1465 or 1480 , today in Berlin, is placed next to the depiction of Queen Sheeba petitioning King Solomon (p. 86). Another deësis is found in the manuscript from 1455, today in The Hunterian Museum in Glasgow (p. 76). The last two depictions do not show Mary with exposed breast.

21. Cf. Jezler, p. 342, ill. 132. The 1425 painting is reproduced as fig. 6.13 in Bynum, Fragmentation and Redemption, p. 225.

22. Cf. Jezler, p. 338, ill. 130.

23. Das göttliche Strafgericht, Domkirche, Graz, Austria, cf. Leopold Kretzenbacher, "Schutzund Bittgebärden der Gottesmutter," fold-out after p. 32.

24. Cf. Luther Exhibition 1983, 335, no. 443; cf. Jezler, p. 191, no. 18.

25. Cf. Jezler, p. 344, no. 133.

26. Active in Cologne between 1460-80, cf. Jezler, p. 342, no. 131.

27. Cf. Luther Exhibition 1983, 335, no. 442; cf. Jezler, p. 187, no. 16.

28. Rijksmuseum Amsterdam Paintings (New York: Newsweek, Simon and Schuster, 1969), p. 27.

29. Cf. Jezler, p. 346, no. 131.

30. Cf. Norbert Lieb and Alfred Stange, Hans Holbein der Ältere (Munich and Berlin: Deutscher Kunstverlag, 1960), p. 115.

31. Cf. Art History Museum Vienna Picture Gallery (New York: Newsweek, Simon and Schuster, 1969), p. 24.

32. Albrecht Dürer 1471 bis 1528. Das gesamte graphische Werk. Druckgraphik. Einleitung von Wolfgang Hütt (Munich: Rogner \& Bernhard, 1971), no. 1628.

33. Cranach's At Death's Door, cf. Max J. Friedländer and Jakob Rosenberg, The Paintings of 
Lucas Cranach (New York: Tabard Press, 1978), ill. no. 97. Today the painting is in the Leipzig Museum of Art; Cranach's Last Judgment, ibid., illustration no. 100. This painting belongs to the William Rockhill Nelson Gallery of Art in Kansas City, Missouri, USA.

34. Cf. Jezler, p. 345, no. 134.

35. Cf. Carl Linfert, Hieronymus Bosch, trans. Robert Erich Wolf (New York: Harry N. Abrams, 1972), p. 84.

36. Provost painted two variations of the motif: Variation 1 is found today in Hamburg, Germany, cf. Werner Hofmann, ed., Luther und die Folgen für die Kunst (Munich: PrestelVerlag, 1983), color plate 4, hereafter Hofmann. Variation 2 is found today in the Stedelijk Museum voor Schone Kunsten at Brugge, cf. Stephan Beissel, Geschichte der Verehrung Marias im 16. und 17. Jahrhundert. Ein Beitrag zur Religionswissenschaft und Kunstgeschichte (Freiburg: Herder, 1910), p. 417, ill. no. 207; Pierroberto Scaramella, Le Madonne del Purgatorio. Iconografia e religione in Campania tra rinascimento $e$ controriforma (Genova: Marietti, 1991), ill. no. 21. Caroline Walker Bynum has a reproduction of Variation 2 in Holy Feast and Holy Fast: The Religious Significance of Food to Medieval Women, Berkeley: University of California Press, 1987), ill. 29.

37. Thus it would be inappropriate to speak here of Christ as the "avenger," since his gesture clearly symbolizes his mercy for humanity. Furthermore, the main "parallel" drawn by the artist is not primarily that of Christ's side wound and Mary's breast, as C. W. Bynum would want it, but most of all the "parallel" or symmetry of the intercessors, Mary and John, who are placed opposite each other and below the merciful Judge, as in Variation 2. Bynum repeated her interpretation in Fragmentation and Redemption, p. 102, that "the wound of Christ and the breast of Mary are clearly parallel in picture after picture." This is not necessarily so in the deësis representations.

38. This is Bynum's caption for ill. 29. It seems to me that in order to arrive at an appropriate interpretation of Provost's painting from Brugge (Bruges; Variation 2), it is indispensable to take a closer look at the Variation 1 (at Hamburg), as it was hinted at here, which leads to an interpretation different from Bynum's, namely that the food/lactation aspect is largely irrelevant in deësis compositions, whereas the intercession (= Greek deësis) is the key to the understanding of the picture. When Jan Provost included Mary and John in his picture, his concern appears to have been to remind the viewer of the intercession (deësis) at the Last Judgment, since these two figures are the classical advocates for the sinners, as the history of the deësis motif shows. The mercy of Christ at the Last Judgment is more clearly depicted in Variation 1 where Christ stretches his left hand out toward the sword without touching it; with his right hand he is ready to grab the lily of mercy without touching it. His hands show the marks of the nails, as does his right foot. His side wound is visible, but he does not point to it as he wants to take the lily of mercy into his hand. That the artist was not primarily interested in any alleged "parallel" between Christ's side wound and Mary's breast may be derived from the fact that in Variation 1 Christ does not point to his wound at all; the wound is hardly visible, while it is both his hands and one foot that show the marks of the nails, which symbolize rather clearly the loving suffering of Christ for the sinners.

39. Cf. Jezler, p. 347 , no. 135.

40. On Luther's sympathetic use of Bernard's sermons, see Franz Posset, "Bernardus Redivivus: 
The Wirkungsgeschichte of a Medieval Sermon in the Reformation of the Sixteenth Century," Cistercian Studies, 22 (1987): 239-49. Bernard's Advent sermons as sources for Luther are studied in Posset, "Bernard of Clairvaux as Luther's Source: Reading Bernard with Luther's 'Spectacles'," Concordia Theological Quarterly, 54 (1990): 281-304, especially pp. 292-98. Luther's use of Bernard's sermons for Christmas, Lent, and Easter are investigated in Posset, "Bernhard von Clairvauxs Sermone zur Weihnachts-, Fasten- und Osterzeit als Quellen Martin Luthers," Lutherjahrbuch, 61 (1994): 93-116; "Divus Bernhardus: Saint Bernard as Spiritual and Theological Mentor of the Reformer Martin Luther," Bernardus Magister. Papers Presented at the Nonacentenary Celebration of the Birth of Saint Bernard of Clairvaux, Kalamazoo, Michigan, Institute of Cistercian Studies, Western Michigan University, 10-13 May 1990, ed. John R. Sommerfeldt (Cistercian Publications \& Citeaux: Commentarii Cistercienses, 1992, 517-32. Theo Bell provided a first comprehensive study on references to Bernard in Luther's writings: Bernhardus Dixit. Bernardus van Clairvaux in Martin Luthers werken (Delft: Eburon, 1989; revised German version, Divus Bernhardus. Bernhard von Clairvaux in Martin Luthers Schriften [Mainz: Verlag Philipp von Zabern, 1993]), from here on I refer to the German edition. Cf. also Theo Bell, "Bernhard von Clairvaux als Quelle Martin Luthers," Bijdragen, tijdschrift voor filosofie en theologie, 56 (1995) 2-18; "Luther's Reception of Bernard of Clairvaux," Concordia Theological Quarterly, 59 (1995): 245-77.

41. I use my own translation of the original which reads as follows:... und S. loannes undt Maria bitten Christum fur uns am Jungsten gerichte, undt die mutter weiset dem Sohn ihre bruste, die ehr gesogen hat, Welches aus S. Bernhards buchern genommen ist undt ist nicht wohl geredet, gemahlet oder gemacht gewesen von S. Bernhardt, unndt man solte noch solche gemelde wegthuen, WA 33: 83, $25-42$ (1531). Cf. Luther's Works (Philadelphia: Fortress Press; and St. Louis: Concordia, 1955-), vol. 23: 57; Bell has a critical note on the translation in Luther's Works (Bell 315, note 150).

42. On Cranach, cf. Friedländer and Rosenberg, ill. no. 100.

43. Cf Wilson, p. 198.

44. Wie dan dis auch ein schendtlich und lesterlich bildt oder gemelde ist von dem Jungsten tage, do man gemahlet hat, wie der Son fur dem vater niderfellet undt zeiget ihm seine wunden ..., WA 33: 83, 25-42 (1531). Cf. Luther's Works, pp. 23:57.

45. On the painting in Luther's dining room, cf. WA TR 2: 207, $22-24$ (no. 1755, 1532); cf. Josef Lieball, Martin Luthers Madonnenbild. Eine ikonographische und mariologische Studie mit 53 Abbildungen (Stein am Rhein: Christiana Verlag, 1981), pp. 14-15; Eric W. Gritsch, "The Views of Luther and Lutheranism on the Veneration of Mary," in The One Mediator, the Saints, and Mary. Lutheran and Catholics in Dialogue VIII, eds. H. George Anderson, J. Francis Stafford, Joseph A. Burgess (Minneapolis: Augsburg, 1992): 235-48, here p. 240; Sergiusz Michalski, The Reformation and the Visual Arts: The Protestant Image Question in Western and Eastern Europe (London and New York: Routledge, 1993), p. 36.

46. Recent studies on Luther's view of Mary include: Eric W. Gritsch, Embodiment of Unmerited Grace. The Virgin Mary According to Martin Luther and Lutheranism (Washington: 1980); Franz Courth, "Das Marienlob bei Martin Luther: Eine Katholische Würdigung," Münchener Theologische Zeitschrift, 34 (1983): 279-92; Alberic Stacpoole, 
ed. Mary's Place in Christian Dialogue (Wilton: Morehouse-Barlow, 1983); Peter Newman Brooks, "A Lily Ungilded? Martin Luther, the Virgin Mary and the Saints," Journal of Religious History, 13 (1984): 136-49. On the developments in Lutheranism, cf. Robert Kolb, For All The Saints: Changing Perceptions of Martyrdom and Sainthood in the Lutheran Reformation (Macon, 1987). Kathleen S. Hurty, "Mary, Luther, and the Quest for Ecumenical Images," Mid-stream 30 (1991): 60-74.

47. Cf. H. M. Stamm, "Die 'Humilitas' Mariens als Ansatzpunkt der Marientheologie und Marienverehrung bei Martin Luther," De Cultu Mariano Saeculo XVI - Acta Congressus Mariologici-Mariani Internationalis Caesaroaugustae 1979 celebrati (Rome, 1985), vol. 3: 161-76, quoted in Michalski 36 and 200, n. 63. Cf. Eduard Stakemeier, "De Beata Maria Virgine Eiusque Cultu luxta Reformatores," De Mariologia et Oecumenismo (Rome: Pontifica Academia Mariana Internationalis, 1962), p. 450.

48. ... da war geschwigen, quod Christus sit redemptor, sed iudicem pingebant cum virga et gladio, das ist als zorn, da mit er die welt wil straffen, deinde pinxerunt lohannem et Mariam, tum cucurrimus ..., WA 37: 207, 34-208, 5. In 1537-40, Luther repeated his objections to Bernard and to Mary's exposed breast, without mentioning John the Baptist, WA 47: 276, 6-26.

49. Cf. Reinhard Schwarz, "Die spätmittelalterliche Vorstellung vom richtenden in Christus ein Ausdruck religiöser Mentalität, " Geschichte in Wissenschaft und Unterricht, 32 (1981): 526-53; "Wurzeln evangelischen VerantwortungsbewuBtseins," Kirchengemeinschaft Anspruch und Wirklichkeit. Festschrift für Georg Kretschmar zum 60. Geburtstag, eds. Wolf-Dieter Hauschild, Carsten Nicolaisen, Dorothea Wendebourg (Stuttgart: Calwer Verlag, 1986): 149-64.

50. Cf. Bell, p. 315.

51. Id.

52. "Also machen sie aus Christo nichts denn einen strengen, zornigen Richter, fur dem man sich furchten musse, als der uns wolle inn die helle stossen, Wie man jn gemalet hat auff dem Regenbogen zu gericht sitzend und seine Mutter Maria und Johannes den Teuffer zu beiden seiten als furbitter gegen seinem schrecklichen zorn," WA 46: 8, 32-36 (On John 16). This text, which mentions the judge on the rainbow, may mirror yet another picture which Luther came across at Wittenberg. It is a stone relief from the end of the fourteenth century which depicts Christ on the rainbow with lily and sword in his mouth (but without Mary and John); cf. Luther Exibition 1983, 129, no. 146. The so-called "double intercession of Christ and Mary" is mentioned as Luther's subject of objection by Michalski, p. 34, but not the deësis.

53. Cf. Franz Posset, Luther's Catholic Christology According to his Johannine Lectures of 1527 (Milwaukee: Northwestern Publishing House, 1988), pp. 185 f.

54. Craig Harbison, Op. cit.; Huston Diehl, "To Put us in Remembrance": The Protestant Transformation of Images of Judgment," Homo Memento Finis: The Iconography of Just Judgment in Medieval Art and Drama, (EDAM Monograph Series 6, 1985), 179-208.

55. Cf. Cranach, ill. no. 221; also called "Law and Grace," cf. Hofmann, p. 210, ill. no. 84, 84a, $84 \mathrm{~b}$. 
76 / Renaissance and Reformation / Renaissance et Réforme

56. Cf. Michalski, p. 39.

57. This Bible was part of the Nuremberg exibition in 1983 in honor of Luther's 500th birthday, cf. Luther Exhibition 1983, 335, no. 445.

58. Cf. WA 10-III: 26, 35; cf. Hofmann, p. 46; Michalski, p. 39.

59. Cf. Hofmann, p. 194, ill. 67 (Berlin, Staatliche Museen).

60. Cf. Schiller, vol. 2, ill. no. 804.

61. Cf. WA 7: 563,35 . 


\section{Book Reviews Comptes rendus}

The Works of John Webster, Volume 1. "The White Devil" and "The Duchess of Malfi," edited by David Gunby, David Carnegie, and Anthony Hammond. Cambridge: Cambridge University Press, 1995. Pp. xxxiv, 713.

This is the first volume of a new, two-volume, old-spelling edition of the Works of John Webster, containing his two best known plays, which William Hazlitt described in 1820 as "upon the whole ... the nearest to Shakespear [sic] of anything we have upon record." Gunby is the biographical and literary editor, Carnegie the theatrical editor, and Hammond - assisted by Doreen DelVecchio - is the bibliographical editor. Each contributes a third of the introduction, and they combine on the full, informative, and frequently witty commentary notes, which even accommodate their occasional disagreements. The result is an impressive and complex piece of scholarship containing a great deal that is valuable and new.

The last complete old-spelling Webster was F. L. Lucas's four-volume edition of 1927. As is to be expected, the present edition goes beyond his work in nearly every aspect, but its most striking difference is the amount of attention it devotes to the performance dimension of the plays. Webster is remarkable among his contemporaries for acknowledging performance and actors in the impedimenta to his plays; and the Cambridge editors adopt the distinction he makes between "Poem" (i.e. the words on the page, intending for reading) and "Play" (those words as presented collaboratively in performance). In acknowledging that both these elements must be subsumed in the "Text" of modern editions. they are following the trail recently blazed by bibliographers such as T. Howard-Hill and D.F. McKenzie, and it is accordingly on this aspect of the edition I shall concentrate in the limited space at my disposal.

The main responsibility for this theatrical element falls on David Carnegie, who emphasizes in his part of the general introduction that stage history constitutes a tradition of "accumulated mimetic criticism" that complements written interpretation of the plays. Besides listing data for all known production of the two strategies, his 